\title{
Sylwia Wójcik
}

\author{
Uniwersytet Rzeszowski
}

\section{Z listów i reportaży ks. Jana Glicy \\ The letters and reports of Priest Jan Glica}

\begin{abstract}
ABSTRAKT
Tematem mojej wypowiedzi uczyniłam problem relacji misjonarza Jana Glicy, polskiego migranta w Brazylii, z przedstawicielami rdzennej ludności stanu Paraná. Wydobyłam znaczenie cezur, które wpisane są w naturę tych relacji. Zwróciłam także uwagę na różnice w odbiorze przyrody polskiej i brazylijskiej. Oczarowany misjami. Listy z Brazylii Jana Glicy to książka zawierająca zarówno zapis osobistych losów narratora, jak i historie spotkanych przez niego ludzi. Reportaże i listy, z których składa się tom, ukazują codzienność pracy duszpasterskiej misjonarza. Dzięki hetorogenicznej formie i wymogom autentyzmu wskazane teksty są źródłem cennych poznawczo spostrzeżeń na temat losów dwudziestowiecznego imigranta

w Brazylii. Chociaż wpisują się w kanon

literatury emigracyjnej, to zajmują osobne miejsce. Dzieje się tak przede wszystkim za sprawą odmiennej motywacji wyjazdu i celów, które przyświecały decyzji o migracji. Jan Glica opuścił Polskę nie pod wpływem przymusu, ale $\mathrm{z}$ uwagi na ewangelizacyjną misję wynikającą z posługi kapłańskiej. Wraz ze zmianą motywu wyjazdu rekonfiguracji ulega całość doświadczeń podmiotu wpływających na kształt aktu rozpoznania otaczającej rzeczywistości.

Motyw emigracji funkcjonujący w rodzimej kulturze zostaje zmodyfikowany, a proces ten znajduje odzwierciedlenie w budowie dzieła literackiego.
\end{abstract}

SŁOWA KLUCZOWE: literatura emigracyjna, Jan Glica, listy, reportaże

\section{ABSTRACT}

The following paper discusses the problem of the relationship between the missionary Jan Glica, a Polish migrant in Brazil, and the representatives of indigenous peoples in the state of Paraná. I have highlighted the significance of caesuras, which are characteristic for these relationships. I also drew attention to the differences in the perception of Polish and Brazilian nature. Oczarowany misjami. Listy z Brazylii [Fascinated by the missions. Letters from Brazil] by Jan Glica is a book about the narrator's life as well as the people the narrator met. Reportages and letters, which are included in the volume, illustrate the everyday pastoral work of the missionary, Priest Jan Glica. Thanks to their heterogeneous form and authenticity, his works are a source of many cognitively valuable insights about the life of the immigrant in Brazil in the twentieth century. Although they belong to the canon of emigrant literature, they have a separate place in it. It results from the different reasons that made the priest leave the country and the goals he had set before he arrived in a foreign land. Jan Glica did not leave his homeland under compulsion, but due to his commitment to the church's evangelizing mission. Because of the distinctive reasons for emigration, a person's experience, which affects the recognition of the surrounding reality, is reconfigured. The emigration motif functioning in the native culture is modified and this process is reflected in the construction of the literary work.

\section{KEYWORDS:}

emigrant literature, Jan Glica, letters, reports 


\section{WSTĘP}

Przedmiotem mojego artykułu jest epistolarna i reporterska twórczość misjonarza należącego do Zgromadzenia Księży Marianów Niepokalanego Poczęcia Najświętszej Maryi Panny, księdza Jana Glicy. Tezą, którą będę starała się udowodnić, jest przekonanie, że twórczość autora poprzez swoje uwarunkowania aksjologiczne i odmienny charakter zajmuje miejsce osobne na agonie polskiej literatury emigracyjnej. Będę starała się to wykazać poprzez analizę motywów, którymi kierują się bohaterowie oraz przez namysł nad językowym kształtem prowadzonych narracji. Celem artykułu jest ponadto udowodnienie, że twórczość Glicy jest przekształceniem tradycyjnych wzorców literatury wychodźczej. Modyfikacją, która podzielając tożsame doświadczenia, nie zaprzecza im, ale uzupełnia i prezentuje w zupełnie nowej optyce uwarunkowanej przez aksjomaty misyjne. Na płaszczyźnie tekstowej uwidacznia się to poprzez wspólnotowość realizowaną w języku i narracji, zastąpienie opozycji swój - obcy przeciwstawieniem nauczyciel - uczeń oraz zastąpienie pesymizmu i tęsknoty optymizmem wynikającym z optyki zadaniowej i poczucia doniosłej misji chrystianizacyjnej. W analizie pomocne okażą się elementy geopoetyki oraz badań kolonialnych, w których widzę dogodne narzędzia analizy tekstu i bohaterów. Stanowią one tekstową reprezentację przekonania o obowiązku chrystianizacji, a więc działania realizowanego na gruncie kultury, w którym spotykają się dwie niesymetrycznie wartościowane grupy czy społeczności.

\section{DZIAŁALNOŚĆ MISYJNA KS. JANA GLICY}

Duchowny urodził się w 1935 roku we wsi Bączki nieopodal Garwolina. W 1952 roku wstąpił do nowicjatu. W 1964 roku w Górze Kalwarii przyjął święcenia kapłańskie. Cztery lata później wyjechał na misje do Brazylii. Przez pierwsze dziesięć lat pracował w parafii w Kurytybie - mieście położonym w stanie Paraná, stanowiącym ważny ośrodek polonijny w Ameryce Południowej. Ambicją i pragnieniem duchownego była religijna posługa wśród ludzi zamieszkałych w tzw. interiorze. Udało mu się wyjechać na prowincję. Jak pisze autor noty biograficznej, w którą opatrzona została przywoływana książka:

Po początkowych rozterkach i niepewnościach, tak rozmiłował się w pracy misyjnej, że został nią oczarowany, a ściśle mówiąc, oczarowali go ludzie [...] żyjący wśród gór i lasów w niezwykle prymitywnych warunkach. Zachwyciła go niespotykana gdzie 
indziej przyroda, piękna i groźna, nadająca rytm życiu biedaków nieodczuwających potrzeby osiągnięć współczesnej cywilizacji ${ }^{1}$.

W 1978 roku Glica został proboszczem w położonym sto czterdzieści kilometrów od Kurytyby mieście Adrianópolis. Stamtąd dojeżdżał do dwudziestu pięciu osad, w których miejsca kultu nie istniały, bądź wymagały gruntownego remontu, a mieszkańcy cierpieli na brak duchowej opieki. Glica w jednym z reportaży sumuje zdobyte doświadczenie:

Ludzie nie mają żadnego pojęcia o Bogu, historii zbawienia, przykazaniach Bożych i kościelnych, sakramentach świętych, głównych prawdach wiary, o Kościele. 95 procent mieszkańców nie umiało samodzielnie odmówić Ojcze nasz czy Zdrowaś Maryjo i nie wiedziało, jak się poprawnie przeżegnać. Winy w tym nie ponoszą żadnej, po prostu nikt ich tego nie nauczył, a bardzo chcieliby się nauczyć2.

Duchowny pracował wśród bardzo biednych ludzi. Jak pisze Stanisław Kurlandzki, misjonarz wzniósł siedem kaplic, które sam zaprojektował, a często i budował własnymi rękami, w dwóch kaplicach przeprowadził zaś kapitalny remont $^{3}$. Po pięciu latach intensywnej i wyczerpującej pracy w interiorze Glica został ponownie przeniesiony do Kurytyby, gdzie tym razem pełnił funkcję proboszcza w parafii pod wezwaniem Świętej Rodziny. Korzystając z doświadczeń zdobytych w poprzednich latach, wykorzystując wrodzony talent do zarządzania, doprowadził do szybkiego ukończenia prac budowlanych w powstającym kościele oraz domu parafialnym w dzielnicy Novo Mundo (Nowy Świat). Talentom organizacyjnym towarzyszyło również zacięcie artystyczne. W 1985 r. Glica wydał dwa śpiewniki. Pierwszy z nich zatytułował Canto Pastorais - Śpiewnik pieśni religijnych. Zawierał on teksty czterystu czterdziestu czterech pieśni oraz krótki zestaw modlitw. Nakład wynosił dziesięć tysięcy egzemplarzy. Kolejną pozycją, którą przygotował i opublikował, był Śpiewnik na Adwent i Boże Narodzenie. Rozbudzany przez Glicę kult Miłosierdzia Bożego w Brazylii księża marianie potraktowali jako specjalną misję, czego skutkiem było oddelegowanie go na rok do Stanów Zjednoczonych, do mariańskiego sanktuarium Miłosierdzia Bożego

\footnotetext{
${ }^{1}$ J. Glica, Oczarowany misjami. Listy z Brazylii, Warszawa 1996, s. 9.

${ }^{2}$ Tamże, s. 100.

${ }^{3}$ S. Kurlandzki, Nota biograficzna, w: J. Glica, dz. cyt., s. 15.
} 
w Stockbridge w stanie Massachusetts. Dzięki zdobytym tam umiejętnościom, po zapoznaniu się ze specyfiką kultu Bożego Miłosierdzia, powrócił do Kurytyby i wzniósł tam ośrodek kultu Miłosierdzia Bożego promieniujący na całą Brazylię 4 . W 1992 r. Glica otrzymał od sióstr zakonnych ziemię na peryferiach miasta. Dwa lata później arcybiskup stanu Paraná, Pedro Fedalto erygował tam parafię, której pierwszym proboszczem został Glica.

Zapis doświadczenia pracy misyjnej w Ameryce Łacińskiej duchowny zawarł w książce będącej zbiorem reportaży i listów. Nadał jej tytuł Oczarowany misjami. Listy z Brazylii (Warszawa 1996). Wybór formy listu - pisanego i zwróconego do nieobecnego tu i teraz adresata - zyskuje szczególne znaczenie w kontekście długiej tradycji twórczości epistolarnej ${ }^{5}$. Listy pisane przez Glicę nawiązują tematycznie do literatury podróżniczej. Stanowią cenne źródło informacji o działalności misyjnej i losach emigranta. Podobnie reportaż, dzięki hetorogenicznej formie i wymogom autentyzmu, jest źródłem wielu wartościowych poznawczo spostrzeżeń na temat losów przybysza z Polski. Materiał fabularny w przypadku omawianej twórczości osadzony jest w empirycznych doświadczeniach misjonarza.

Jak już zaznaczyłam, wspomnienia kapłana są świadectwem jego działalności misyjnej. Już ta informacja eksponuje podstawową różnicę pomiędzy jego doświadczeniem a przypadkami emigracji wojennej, zarobkowej czy politycznej. Misjonarz wyjechał z kraju nie z przyczyn politycznych, lecz jako duchowny, reprezentant Kościoła katolickiego. Ta transfiguracja doświadczenia musiała odnaleźć odzwierciedlenie również w wizerunku bohatera oraz w kształcie etosu towarzyszącego jego działalności w Ameryce Południowej. Nieustanna praca i bycie stale w drodze to dość swobodne przekształcenie figury bezdomności. Nie jest już nią bowiem wygnanie z ojczyzny i znój znoszony w związku z walką o nią. Pod pojęciem ofiarności w tym przypadku ukrywa się raczej nieustanna praca na rzecz innych oraz konieczność podporządkowania się zwierzchnikom Kościoła. Misjonarz przenoszący się z miejsca na miejsce nieustannie coś zdobywa i nieustannie traci: miejsca, ludzi, relacje. Bezdomność jest więc wolnym wyborem bohatera, za którym kryją się określone wartości chrześcijańskie. Przecież nie przymus lub widmo presji politycznej zmusiły go do porzucenia stabilnego stylu życia, ale przekonanie o doniosłej misji chrystianizacji. Misjonarz jest dysponentem

${ }^{4}$ Tamże, s. 16.

${ }^{5}$ Słownik literatury polskiej XX wieku, red. J. Sławiński, Wrocław 1992, s. 272. 
wartości ważnych z punktu widzenia religii. $\mathrm{W}$ jego relacjach spojrzenie historyczne zostaje zastąpione optyką aksjologiczną, a wątki narodowe przeobrażają się w perspektywę kosmopolityczną.

\section{OCZAROWANY MISJAMI. LISTY Z BRAZYLII}

Przedmiotem opowieści w Oczarowany misjami. Listy z Brazylii są zarówno osobiste losy narratora, jak i historie spotkanych przez niego ludzi. Reportaże i listy, z których składa się tom, ukazują codzienność pracy duszpasterskiej. Pierwszą część książki wypełniają reportaże. Można wyodrębnić kilka podejmowanych w nich tematów: pierwsze misyjne kroki, praca i jej przebieg, misjonarska codzienność oraz zdarzenia wyłamujące się z codziennego porządku. Glica wiele miejsca poświęca pierwszym dniom pobytu na misjach, które dla każdego kapłana podejmującego decyzję o pracy duszpasterskiej poza ojczyzną są intensywne i bardzo trudne. Znajduje się on bowiem w całkiem nowej rzeczywistości, w której nierzadko czuje się zdezorientowany. Glica myśląc o misyjnych trudach, pisze:

Brazylia to kraj szalenie zróżnicowany, pełen przeciwieństw, kontrastów. Misjonarz napotyka tam olbrzymie trudności. Już sam fakt, że przeważnie pochodzi z Europy oddalonej o tysiące kilometrów, utrudnia mu kontakt z parafianami. Jest zdany na siebie, gdyż nie zawsze może otrzymać pomoc. Na odpoczynek brak mu czasu. Nie ma z kim podzielić się swymi radościami i przykrościami, czego potrzebuje każdy człowiek $^{6}$.

Misjonarz odkrywa, jak wiele w rzeczywistości interioru zaskakuje go, nawet przeraża. Czując instynktowny lęk, jednocześnie podziwia bujność deszczowych lasów, ich urodę, naturalność zachowania rdzennych mieszkańców. Odczuwa różnicę pomiędzy ludźmi, wśród których pracuje a sobą, przybyszem z Europy. Dążąc do uniwersalizacji własnego doświadczenia, odwołując się do myślenia wspólnotowego, także pisząc o czekających go wyzwaniach, używa narracji trzecioosobowej. Ton jego wypowiedzi staje się wówczas wzniosły. Zupełnie innej techniki pisarskiej używa, gdy jego uwaga przenosi się na opis codziennego trudu. Tok opowieści staje się wtedy dynamiczny, zdania są krótkie i dominują liczne wyliczenia, które służą ekspozycji podejmowanego znoju, mnogości koniecznych

${ }^{6}$ J. Glica, dz. cyt., s. 20. 
do wykonania zadań i ich różnorodności. Chwile intensywnie przeżywanej fascynacji pierwotnością, dzikością natury przeplatają się z przedstawieniami przeżywania smutku, niepokoju, niechęci, rozczarowania. Zadania stojące przed kapłanem - misjonarzem są trudne, wymagają samozaparcia, konsekwencji, wysiłku fizycznego i psychicznego. Ważne miejsce w strukturze opowieści zajmuje przedstawienie procesu nawiązywania relacji z rdzennymi mieszkańcami i zacieśniania więzi społecznych. Najczęściej mieszkańcy, z racji pełnionej przez duszpasterza funkcji, okazywali mu sympatię, dawali wsparcie. Skala tej sympatii pozwalała zapomnieć o trudach podróży odbywanej w ciężkich warunkach, o niebezpiecznych czyhających na drogach lub przepięknych, ale trudnych do przebycia szlakach, które zmuszony był pokonać, by dotrzeć do wiernych. W jednym z reportaży autor wspomina:

Zeskakując z konia, prawie usiadłem na ziemi, gdyż po kilkugodzinnej jeździe nieprzyzwyczajone nogi zupełnie zdrętwiały. Podszedł do mnie stary, wysoki Murzyn, przywitał się i powiedział uroczyście:

- Razem z padre przybył dziś do naszej biednej kaplicy i do nas sam Chrystus. Gdy mówił ostatnie słowo, pochylił się nisko ze czcią. Ucałował moje ręce, a ja czułem się trochę zakłopotany i skrępowany, lecz jednocześnie zbudowany głęboką wiarą tego prostego człowieka ${ }^{7}$.

Zaufanie, o którym wspomina Glica, związane było z tym, że misjonarz pełnił funkcję duchowego opiekuna wspólnoty plemiennej. Stał się pośrednikiem między Bogiem a ludźmi. W warstwie przedstawionej scena zyskuje ukształtowanie wertykalne, odzwierciedlające opozycję sacrum i profanum. Utrzymywanie dobrych relacji międzyludzkich stworzyło misjonarzowi przychylną i odpowiednią atmosferę pracy. $\mathrm{W}$ jego reporterskiej relacji pobyt w interiorze Brazylii postrzegany jest nie w kategoriach izolacji, ale współdziałania z lokalną społecznością. Możliwa staje się również asymilacja z tamtejszym środowiskiem, która w tradycyjnych ujęciach literatury emigracyjnej - z powodu różnic kulturowych i aksjologicznych - była często niemożliwa lub - w świetle przekonań o tymczasowości pobytu i jego pragmatycznych celach - zbędna ${ }^{8}$. Inaczej jest w przypadku Glicy.

${ }^{7}$ Tamże, s. 41-42.

${ }^{8} \mathrm{~W}$ świetle powyższych słów kategorię emigracji rozumiem jako przymusowe wychodźstwo i niemożliwość asymilacji, misje zaś jako dobrowolne opuszczenie kraju, kierowane ideą religijną. 
Bohater nie tylko nawiązuje kontakt z ludnością, ale zakorzenia się, wrasta w nią i staje się jej częścią. Oczywiście nie jest to związek symbiotyczny. W pisanych kilka dekad wcześniej relacjach wyczuwamy sugerowaną i sygnalizowaną za pomocą języka przewagę intelektualną narratora. Misjonarz pisze z perspektywy kogoś, kto przynosi wiedzę, działa w ramach misji i procesu chrystianizacji. Świadomie lub nie, korzysta z narzędzi przemocy kulturowej będącej owocem przekonania o hegemonii Zachodu. Odzwierciedlenie tego faktu znajdziemy w konkretnych ujęciach językowych i fabularnych (np. „pochylił się nisko z czcią” itd.).

\section{Oczarowany misjami. Listy z Brazylii Jana Glicy to książka zawierająca zarówno zapis osobistych losów narratora, jak i historie spotkanych przez niego ludzi.}

Relacje Glicy wyróżnia spośród nostalgicznych często w tonie wypowiedzi emigrantów przekonanie o celowości swojego działania oraz optymizm, wiara w moc wartości, których jest reprezentantem i którymi dzieli się z ludźmi, do których przybywa. Listy i reportaże Glicy są, mimo opisywanych trudności, świadectwem zaangażowania i nadziei na przyszłość. Rzeczywistość, w którą jest zanurzony staje się źródłem, z którego podmiot czerpie poczucie szczęścia. Troska o dobro wiernych - podopiecznych, dzielenie kłopotów i radości z ludźmi, do których się jest posłanym to postawa, która pozwala budować zaufanie i staje się podstawą współpracy. Duchowni zwykle dopiero po wypracowaniu tego typu więzi mogą przystąpić do realizacji misyjnych celów: budowania szkół i kościołów, organizacji edukacji, polepszenia standardów życia, katechizacji, tworzenia grup wiernych. Momenty smutne i tragiczne, jak choroby i śmierć oraz chwile radosne, jak narodziny nowych członków społeczności pomagają w budowaniu i podtrzymywaniu relacji misjonarza z miejscowymi ludźmi. Wydarzenia te przeżywane są wspólnotowo. Glica wspomina, że postrzegano go jako „cudownego uzdrowiciela”, który niesie ukojenie w momencie śmierci. Na płaszczyźnie języka uwidacznia się w nomenklaturze używanej przez rdzenną ludność szacunek wobec księdza. Określany jest mianem „padre”, które konotuje cechy takie, 
jak szacunek, autorytet, a czasem nawet poddaństwo wynikające z pełnionej roli społecznej. W przekonaniu miejscowej społeczności duchowny poprzez rozgrzeszenie mógł zapewnić szczęśliwe życie po śmierci. Glica troszcząc się o chorych doznawał wdzięczności. Wielokrotnie na twarzach ludzi widział ogromną radość z możliwości spotkania się z Bogiem. Misjonarz wspomina:

Wszedłem do chaty. Z walizeczki robię ołtarzyk na glinianej, wyboistej podłodze, zapalam świeczkę i kładę Najświętszy Sakrament. Następnie spowiadam chorą, udzielam namaszczenia i Komunii świętej. Biedna kobieta płaszcze ze szczęścia i ja jestem wzruszony, bo nigdy nie marzyłem, że będę mógł przynieść Pana Jezusa aż tutaj.

Osoby prześladowane, poddawane ostracyzmowi społecznemu, bądź mające problemy innego typu poszukiwały pomocy u misjonarza. Duchownych traktowano bowiem jako gwarantów sprawiedliwości, ostateczną instancję odwoławczą we wszelkich trudnych sytuacjach. Zażegnywali oni bowiem konflikty i starali się odnaleźć rozwiązanie w sytuacjach pozornie bez wyjścia. Rozeznanie motywów ludzkiego postepowania, źródła zachowania oraz słabości były efektywnym orężem w ręku misjonarza. Odpowiednie podejście pozwalało osiągnąć zamierzone cele, uzyskać przychylność rdzennej ludności. Pragmatyczne podejście autora wyraża charakterystyczny, sprawozdawczy styl. Budują go przede wszystkim krótkie zdania, będące enumeracją kolejnych podejmowanych czynności. Znacząca jest także pierwszoosobowa perspektywa narracji, wyrażona zaimkiem osobowym lub odpowiednią formą czasownika, konkretyzująca wymiar doświadczenia. Bieg wydarzeń odzwierciedlony w toku fabularnym staje się, z uwagi na doniosłość, ważniejszy niż sam opis. Stąd bierze się tak mała liczba przymiotników czy przywoływanych kontekstów ${ }^{10}$.

Omawiana twórczość jest nie tylko interesującym przedmiotem dociekań stylistycznych, równie ważna jest jej funkcja poznawcza. Listy i reportaże są ważnym źródłem wiedzy na temat charakteru pracy ewangelizacyjnej. Glica wiele miejsca poświęca opisowi misjonarskiej codzienności, której nieodłącznymi elementami są: wędrowanie, nauczanie, katechizowanie, udzielanie sakramentów (zwłaszcza spowiadanie), chrzczenie, odprawianie mszy świętej i cierpliwe

${ }^{9}$ J. Glica, dz. cyt., S. 53.

${ }^{10}$ Osobną kwestią jest, czy taki zapis jest wynikiem świadomie realizowanej strategii pisarskiej, czy stanowi nieuświadomiony nawyk. 
głoszenie prawd nauki chrześcijańskiej, kupowanie leków, doglądanie budowy szkół, kaplic czy szpitali ${ }^{11}$. Jak mówi: Nasze życie musi być ubogie, a serce otwarte na ludzkie potrzeby"12. Misją jest przebywanie z ludźmi biednymi, wykluczonymi, chorymi, znajdującymi się na marginesie lokalnych społeczności oraz zabieganie o podstawowe dla nich dobra. Glica wyznaje:

Co najmniej 80 procent ludności to analfabeci [...]. Poziom intelektualny ludności jest bardzo niski. Ludzie ci nie mają aspiracji i planów życiowych, nie są zdolni do inicjatywy, poszukiwań, postępu i rozwoju. Mają rozmiary dorosłych, a myślenie dziecka. Kierują się emocjami i uczuciami, reagują gwałtownie, są zmienni i nieodpowiedzialni ${ }^{13}$.

Z powyższego fragmentu można odczytać nie tylko informacje statystyczne dotyczące kondycji społeczeństwa i jego poziomu edukacji. Równie interesujący jest stosunek samego narratora do tubylców, który ujawnia się poprzez określoną konstrukcję wypowiedzi. Podobnie, jak we wcześniej przywoływanej opozycji sacrum - profanum, tutaj lud charakteryzowany jest przez dualizm dorosły - dziecko. Narrator wypowiada się o nim w ten sposób wprost. Posługuje się wyrażeniem „myślenie dziecka”. Można z tego wywnioskować, że taka konstrukcja literacka, w której świat przedstawiony budowany jest biegunowo, to specyficzna cecha twórczości Glicy. Umożliwia ona wyeksponowanie nie tyle obcości spotykających się światów, ile niesymetrycznego charakteru relacji. Misjonarze postrzegani są jako dojrzali dorośli, a więc ci, którzy dysponują narzędziami poznawczymi i postawą moralną gwarantującymi możliwość zapewniania warunków sprzyjających rozwojowi duchownemu misji. Troska o wzrost moralny podopiecznych zyskuje tekstowe uzewnętrznienie w leksemie dzieci konotującym takie wartości, jak czułość, opieka czy wychowawcza odpowiedzialność.

${ }^{11}$ Wyliczane w tekście codzienne czynności narratora przyjmują figurę koła odzwierciedlającego ich cykliczność i powtarzalność. niejasne Opisywana zasada realizowana jest również przez powtarzanie konstrukcji składniowych i środków stylistycznych. Autor wyłamuje się z konwencji tradycyjnych narracji emigracyjnych bazujących na spojrzeniu profetycznym, charakteryzującym się linearnością toku opowieści.

${ }^{12}$ J. Glica, dz. cyt., s. 173.

${ }^{13}$ Tamże, s. 95-96. 


\section{RELACJA CZŁOWIEK - PRZYRODA W TWÓRCZOŚCI KS. JANA GLICY}

Przedstawione przez Glicę życie misjonarza w Ameryce Południowej przystaje do powszechnych wyobrażeń Europejczyków. Ich życie jest ciężką, fizyczną pracą. Często przeżywają silne emocje, trudności związane z klimatem czy nieznanymi dotąd chorobami tropikalnymi. Są oddani ludziom, z którymi pozostają w intensywnych kontaktach. Wiara nadaje sens ich poczynaniom i pozwala przetrwać kolejny dzień. W monotonnej pracy misyjnej wykonywanej każdego dnia zdarzają się chwile i momenty szczególne, które wyraźnie zapisały się w pamięci Glicy. Takim szczególnym momentem było ukąszenie przez jadowitego węża. Narrator przywołuje okoliczności towarzyszące temu zdarzeniu. Działo się to tuż po przybyciu do Rio Natal:

Pospiesznie opuściłem samochód [...] Buty mi się zapadały jak w mięciutką szczoteczkę. Nagle krzyknąłem i odskoczyłem przerażony. Zdawało mi się, że noga poślizgnęła mi się na jakimś miękkim wałku. Nadbiegł kierowca, nie wiedząc, co się stało. Czarno-brunatny wąż umykał zygzakami w krzaki. Pod ręką nie było ani kija, ani kamienia. Moje szczęście, że byłem w butach. Pan Wiktor pokazał mi na lewym bucie płyn jadu i ślad zębów gada. Stałem blady i cały się trząsłem z wrażenia ${ }^{14}$.

Dzikie zwierzęta i tropikalne choroby stanowiły realne zagrożenie. W jednym z reportaży zatytułowanym Praca $w$ interiorze misjonarz pisze:

Nie możemy tutejszych traw, drzew i buszu porównać do europejskich czy północnoamerykańskich, gdzie na trawie, w cieniu drzew można spokojnie odpocząć, a nawet położyć się i zasnąć. W tutejszych trawach, często wysokich do pasa, jest pełno robactwa, różnych gatunków mrówek, pająków, a także jadowitych węży. Nawet psy i inne zwierzęta ostrzeżone przez instynkt nie chcą się położyć na trawie, lecz obierają na legowisko środek drogi albo czysty plac ${ }^{15}$.

Można mówić o swego rodzaju dualizmie doświadczenia - pozytywnie wartościowanej i przyjaznej społeczności lokalnej oraz niebezpiecznej przyrodzie. Kapłani nierzadko znajdowali się w sytuacjach wymagających zimnej krwi i opanowania. Przytrafiające się zdarzenia losowe mogły reorientować dotychczasowy

\footnotetext{
${ }^{14}$ Tamże, s. 68.

15 Tamże, s. 115-116.
} 
model misyjnej pracy i duszpasterstwa. Barwność fauny i flory, odmienne zwyczaje, szczególne wydarzenia dawały misjonarzom okazję do sprawdzenia się w swej roli mistrza, nauczyciela i przewodnika, a przede wszystkim kapłana. Natura kraju pochodzenia jawiła się osadnikom jako miejsce bezpieczne, w którym można było spokojnie egzystować. Poprzez obcowanie z nią budowano osobistą relację z tym, co wokół. Zupełnie inaczej wyglądał kontakt z zastanym na miejscu środowiskiem naturalnym. Respekt wobec przyrody odmiennej od tej znanej z rodzinnych stron i sposób jej charakteryzowania, pełny leksemów o charakterze negatywnym i tożsamych porównań, wydaje się stałym elementem literackiego obrazowania literatury emigracyjnej, której akcja toczy się w Ameryce Południowej. Oto przykład z jednej z powieści ważnego dla brazylijskiej polonii pisarza Jana Krawczyka:

Przede wszystkim - ta gęstwina! Ani nosa w nią wrazić, ani wzrokiem ją przeniknąć. Jedna zbita ściana! A za nią mrok, wilgoć, woń gnijących liści i tajemnicze szmery. Właściwie Franczak nigdy nie czuł obawy przed lasem. Wychowywał się bowiem na jego skraju i zżył się z jego szumem i zapachem. Tylko że tamten las, który teraz wspominał, był inny, jakiś przytulny, pełen nabożnego skupienia i ciszy, przesycony zapachem liści i traw, wonią kwiatów i jagód. Natomiast ten tu, splątany sznurami lian, warkoczami bambusu, poprzetykany olbrzymimi paprociami i drzewiastymi pokrzywami, przejmował go dreszczem grozy i budził posępne myśli. Któż mógł odgadnąć, co krył w sobie i przed czym należało się wystrzegać $[\ldots]^{16}$.

W powyższym fragmencie została ukazana nierówna relacja pomiędzy przybyszem z Polski a brazylijską przyrodą. Przeciwstawienie ma charaktery mentalny i skupia się na porównaniu, którego bieguny można określić jako tam-tu. To zabieg literacki, który jest charakterystyczny dla tego typu literatury. U Glicy ma on jednak znacznie mniejsze natężenie, wszak bohater tę obcość natury i dyskomfort tym wywołany tłumaczy sobie i rekompensuje doniosłym znaczeniem swojej misji. To, co dla Krawczyka jest przeciwnością, dla Glicy staje się poświęceniem.

Wspólne wszystkim misjonarskim relacjom jest także poczucie bycia potrzebnym, szanowanym i ważnym dla lokalnej społeczności. Autentyczna postawa religijna pozwala kapłanowi uzyskać niezbędne zaufanie i autorytet. Najbardziej istotna okazuje się nie edukacja szkolna czy religijna w kościołach (np. kazania),

${ }^{16}$ J. Krawczyk, Pampa, Lublin 1985, s. 5. 
ale żywa katechizacja poprzez uczynki i sposób życia misjonarzy, bliskość w kontaktach $\mathrm{z}$ autochtonami. W ten sposób misjonarze mogli dawać dobre świadectwo nie tylko o samych sobie, ale i instytucji kościelnej, którą reprezentowali.

\section{Dzięki hetorogenicznej formie i wymogom autentyzmu wskazane teksty są źródłem cennych poznawczo spostrzeżeń na temat losów dwudziestowiecznego imigranta w Brazylii.}

W książce Glicy interesująco prezentują się także doświadczenia kontaktu z Innym ${ }^{17}$. Mieczysław Dąbrowski pisze, że opozycja swoje - obce w tle sugeruje obecność cezury, granicy, przejścia między jednym a drugim polem. Zwracając uwagę na antropologiczną analizę tego pojęcia, można dostrzec wiele propozycji rozumienia sytuacji wyznaczania granic pomiędzy tym, co jest „nasze” i „obce”. Tę sytuację możemy rozumieć jako przejście od sacrum do profanum, gdyż w obrębie "naszego" świata wytwarzamy zawsze pewien rodzaj centrum, jakieś sacrum właśnie, „podczas gdy wszystko to, co znajduje się na zewnątrz, czego nie znamy, co zagraża, rozumiane bywa jako świat brudny, obcy i przeklęty"18. Bohater reportaży i listów Glicy znajduje się w obcym środowisku, co powinno wywołać poczucie osamotnienia i próby definiowania własnej tożsamości w kontrze do Innego - rdzennego mieszkańca, przedstawiciela innej rasy. Ten wzorzec jest realizowany częściowo. Opozycja swój - obcy nigdy nie urasta do rangi przeszkody czy elementu zakłócającego komunikację. Spotkanie z przedstawicielami obcej kultury - w tradycyjnych ujęciach albo spychane na margines, albo traktowane

${ }^{17}$ Zainteresowany czytelnik wnikliwe informacje na temat kategorii Innego znajdzie w książkach: Inny, inna, inne: o inności w kulturze, red. M. Janion, Warszawa 2004; Inny/Obcy w literaturze, kulturze i języku, red. A. Myszka, E. Oronowicz-Kida, J. Pasterska, Rzeszów 2017; Inny w podróży. Literackie świadectwa podróży na przestrzeni wieków, red. 0. Weretiuk, M. Rabizo-Birek; współpr. I. Bierowiec, M. Zatorska, Rzeszów 2017; Literackie portrety Innego. Inni i Obcy w kulturze, red. P. Cieliczko, P. Kucińskiego, t. 3, Warszawa 2008.

${ }^{18}$ M. Dąbrowski, Swój/obcy/inny. Kontynuacja, „Anthropos?” nr 12-13, 2009, http:// www.anthropos.us.edu.pl/anthropos7/texty/dabrowski.htm, 15.03.2020. 
w kategoriach nieprzyjemnych konieczności - w analizowanej twórczości staje się centrum organizującym cały układ fabularny. Działanie bohatera zawsze odbywa się wobec Innego. Nigdy jednak nie jest to relacja negatywna. Różnice kulturowe, choć istnieją, nie zakłócają procesu porozumiewania się. Relacja z Innym podlega więc znaczącej modyfikacji. Spotkanie z kulturą rodzimą nie wywołuje marginalizacji narratora. Wręcz przeciwnie, dochodzi do swego rodzaju konsolidacji tożsamości. Indywidualizm zostaje zastąpiony modelem wspólnotowym, a wszystko dzięki uznawanym przez obie strony wartościom chrześcijańskim ${ }^{19}$.

Drugą część książki (znacznie mniej rozbudowaną) aniżeli pierwsza, wypełniają listy. Glica niektóre zamieścił w całości, inne przywołał jedynie we fragmentach. Adresatami zamieszczonej korespondencji są najczęściej osoby duchowne. Z niektórymi był w stałym kontakcie listownym, np. z ks. Antonim Łosiem, przełożonym domu zakonnego w Górze Kalwarii, ks. Witoldem Niecieckim, przełożonym Prowincji polskiej, ks. Jerzym Groszewskim, redaktorem „Immaculaty”, ks. Bernardem Backielą, redaktorem „Róż Maryi” w USA, ks. Stanisławem Kurlandzkim, dyrektorem Sekretariatu Misyjnego Księży Marianów w Warszawie. Cechą charakterystyczną korespondencji ks. Glicy jest to, że każdy z jego listów został opatrzony tytułem, który jest zapowiedzią jego treści. „Pierwsze wrażenia”, „Perspektywy nowej pracy”, „Boże Narodzenie w środku lata”, „Jeszcze o kolędzie”, „Życzenia wielkanocne”, „Wizytacja przełożonych i budowa domu” - to niektóre z nich. Nagłówki są krótkie i mają charakter opisowy, niemal reporterski. Wskazują na materię charakteryzowanych wydarzeń i podkreślają pragmatyzm doświadczenia emigracyjnego. Ponadto, każdy list-sprawozdanie ma klasyczną budowę i zawiera: nagłówek, treść właściwą oraz podpis. Spoglądając na zwrot do adresata czytelnik może stwierdzić, czy list ma charakter oficjalny (np. „Czcigodny Ojcze Prowincjale!”) czy prywatny, skierowany do przyjaciół autora (np. „Drogi Edziu!”, „Kochany Stefciu!”). W zakończeniach tych ostatnich widnieją podpisy ks. Glicy „Janek”, w oficjalnych - „Ksiądz Jan Glica MIC”.

W korespondencji Glica porusza tematy dotyczące codziennego życia. Wspomina o nauce języka, pogodzie, świętach i budowach. Niejednokrotnie ubolewa nad tym, że nie wszyscy adresaci odpisują na wysyłane do nich listy. Nadawca do listów dołącza fotografie, które nie stanowią jedynie elementu ilustracyjnego, ale budują znaczenie całości korespondencyjnego dialogu. Funkcja sprawozdawcza

\footnotetext{
${ }^{19}$ Tamże.
} 
obrazująca codzienne rytuały misyjne tylko niekiedy zakłócona zostaje uwagami natury ogólnej, które mają istotne znaczenie dla wymowy korespondencji. Dzieje się tak w następujących fragmentach:

Gdyby ktoś był ciekawy, czy tęsknię za Polską i czy chciałbym wrócić, to szczerze mówię - nie! Tu jest też piękna praca i wielki świat, wprost cudowny. Teraz gdy naukę mogę już wydukać po portugalsku, jestem szczęśliwy i wdzięczny za to, że mnie tu wysłano ${ }^{20}$.

W innym miejscu:

Ciekawe, że na tej ziemi Niemcy z Polakami żyją, pracują i zamieszkują razem i nie ma wojen lub kłótni między nimi. Powiedziano mi nawet, że sąsiedzi pochodzenia niemieckiego są lepsi od rodaków. Pana Kellera, który mieszka obok szkoły i ma samochód, nazywają swoim ojcem i dobroczyńcą. [...] To jest wzruszające, gdy się ma w pamięci przeżyty w Europie koszmar wojny i przelanej krwi ${ }^{21}$.

Uzewnętrznienie przemyśleń autora na temat swojej pozycji na emigracji lub możliwości budowania relacji w odniesieniu do biegu wielkiej historii uwypukla jego zdolności intelektualne. Na zasadzie kontrastu podkreśla pragmatyczne cele, które spełnia analizowana korespondencja, realizująca się głównie za pomocą funkcji sprawozdawczej. Język listów ma niebagatelne znaczenie w tym kontekście. Prosta budowa zdania świadczy o emocjonalności oraz o ich specyficznym, zamkniętym charakterze. Nie należy zapominać, że - nawet jeśli pisane w tonie oficjalnym i przeznaczone do przełożonych - listy są świadectwem komunikacji odbywającej się wewnątrz zgromadzenia ludzi wyznających podobne wartości oraz posiadających tożsame cele. W związku z tym nie dziwi obecność językowych znaków tej wspólnotowości, bezpośrednich apostrof, licznych enumeracji przywołujących imiona i nazwiska współbraci, których zidentyfikowanie nie stanowi problemu dla członka zgromadzenia czy odwoływanie się do wspólnej wiedzy oraz specyficznej dla środowiska nomenklatury.

0 wspólnotowości mogą świadczyć także znajdujące się w korespondencji kolokwializmy, np. „Wyobrażam sobie, że z powodu choroby księdza Stasia

\footnotetext{
${ }^{20}$ J. Glica, dz. cyt., s. 190.

${ }^{21}$ Tamże, s. 75.
} 
Malińskiego roboty macie mnóstwo"22. Użycie tego typu wyrażeń mówi przede wszystkim o spójności grupy i naturalnym charakterze prowadzonej komunikacji. Ich obecność dowodzi jeszcze jednego. Brak wyszukanych środków stylistycznych, prostota oraz pojawiające się leksemy niższego rejestru każą sądzić, że listy nie były pisane z myślą o druku. Realizują one przede wszystkim funkcję komunikacyjną, a najważniejszymi zasadami organizującymi ich strukturę jest ekonomizacja języka, rozumiana jako wyrażenia maksymalnej ilości treści za pomocą ograniczonych środków językowych oraz precyzyjne przekazanie komunikatu. W związku z powyższym język oraz strukturę przywoływanych listów należy analizować przede wszystkim w kontekście wymiany informacji, a nie wyłącznie przez pryzmat środków obrazowania estetycznego. Te, choć istnieją w ograniczonej ilości, pełnią funkcję lustra mechanizmów społecznych.

\section{Reportaże i listy, z których składa się tom, ukazują codzienność pracy duszpasterskiej misjonarza.}

Nie bez znaczenia są także zmiany w narracji listów. Niejednokrotnie, szczególnie w zakończeniach prowadzonej korespondencji, obserwować możemy porzucanie subiektywnej, pierwszoosobowej narracji na rzecz liczby mnogiej. Jako przykład posłużyć może fragment: „Naszym Przyjaciołom i Dobrodziejom, których nie stać na fundację kaplicy, sugerujemy udział w kupnie pomocy katechetycznych, Pisma Świętego, dzwonów, wołających na nabożeństwa itd."23. Zmiana formy narracji wyraźnie sugeruje poczucie wspólnotowości, szczególnie podkreślane podczas gromadzenia funduszy na rozwój ośrodka misyjnego. Spowodowane jest to rzeczywistym poczuciem kolektywności podejmowanego trudu, ale także chęcią nadania prośbie większej wagi znaczeniowej poprzez odwołanie się do autorytetu całego zgromadzenia. Uwagę zwracają także liczne zdrobnienia imion oraz rzeczowników odnoszących się do kultu. Niejednokrotnie w tekście możemy zauważyć deminutywy odnoszące

\footnotetext{
22 Tamże, s. 188.

23 Tamże, s. 233.
} 
się do obiektów związanych z wyznawaną wiarą, które obrazują stosunek podmiotu wypowiadającego do otaczającego świata i wprowadzają, choć na nieco infantylnych zasadach, hierarchizację wartości w obrębie doświadczanej rzeczywistości. Oto przykład: „Przed świętami cały tydzień przebywałem u księdza Henryka Tomaszewskiego i wykonałem trzy skromne szopeczki w dwóch kościołkach i jednej kaplicy”24. Zdrobnienia „szopeczki” oraz „kościółkach” sugestywnie przedstawiają relację podmiotu do elementów związanych z wyznawaną wiarą i wyznaczają niejednorodną strukturę prezentowanego językowego obrazu świata, w którym dominującą rolę odgrywają przedmioty związane $\mathrm{z}$ pracą duszpasterską. Wymienione środki językowe stanowią element stylu stosowanego przez autora listów i pośredniczą pomiędzy doświadczeniem pracy na emigracji a jego tekstualnym wyrazem, w którym obrazowość zostaje zastąpiona opisowością, a wyszukane środki estetyczne ustępują na rzecz prostych stwierdzeń i enumeracji. Wynika to przede wszystkim z pragmatycznych celów prowadzonej korespondencji. Sprawozdawczy styl służy przekazaniu informacji istotnych dla odbiorcy znającego realia pracy duszpasterskiej. Przyczynia się też do realizacji celów, którymi są przede wszystkim relacja z postępów prowadzonej pracy oraz wzajemne podtrzymywanie chrześcijańskiego ducha misyjnego.

\section{ZAKOŃCZENIE}

Jak widać, literatura emigracyjna może stanowić interesujący kontekst do opisu relacji misjonarzy. Szczególnie ciekawie wygląda zestawienie doświadczenia wychodźczego misjonarza i emigrantów politycznych. Mimo że istnieją cechy wspólne, oba rodzaje narracji mają również znaczące punkty różnicujące. W listach i reportażach ks. Glicy widoczne jest charakterystyczne dla twórczości powstającej poza granicami kraju oswajanie obcej rzeczywistości i bycie emisariuszem wartości. Nie mają one jednak wymiaru narodowego, a religijny. Odmienne są także cele działalności bohatera. To już nie inicjowanie walki o polskość i postawa depozytariusza wartości polskich przyświeca jego posunięciom, a troska o szerzenie i pogłębianie wiary oraz pomoc w codziennych problemach podopiecznych. Należy więc przyjąć, że twórczość Glicy, choć powstała na obczyźnie i ma wiele

${ }^{24}$ Tamże, s. 189.

KULTURA - MEDIA - TEOLOGIA 41/2020 
punktów wspólnych z literaturą emigracyjną, zajmuje na jej tle miejsce osobne. Wynika ona z ducha uniwersalistycznej misji szerzenia wiary chrześcijańskiej wśród tych, którym była ona „obca”.

\section{BIBLIOGRAFIA}

Dąbrowski Mieczysław, Swój/obcy/inny. Kontynuacja, „Anthropos?” nr 12-13, 2009, http://www.anthropos.us.edu.pl/anthropos7/texty/dabrowski.htm, 15.06.2020.

Glica Jan, Oczarowany misjami. Listy z Brazylii, Warszawa 1996.

Inny, inna, inne: o inności w kulturze, red. M. Janion, Warszawa 2004.

Inny/Obcy w literaturze, kulturze i języku, red. A. Myszka, E. Oronowicz-Kida, J. Pasterska, Rzeszów 2017.

Inny w podróży. Literackie świadectwa podróży na przestrzeni wieków, red. O. Weretiuk, M. Rabizo-Birek; współpr. I. Bierowiec, M. Zatorska, Rzeszów 2017.

Kłoskowska Antonina, Kultury narodowe u korzeni, Warszawa 1996.

Krawczyk Jan, Pampa, Lublin 1985.

Literackie portrety Innego. Inni i Obcy w kulturze, red. P. Cieliczko, P. Kuciński, Warszawa 2008.

Oblicza Jezusa Chrystusa w kulturach i religiach świata, red. T. Szyszka, A. Wąs, Warszawa 2007.

Różański Jarosław, Główne kierunki kształtowania duchowości misjonarza, w: Przygotowanie misjonarzy - założenia i praktyka, red. J. Różański, Warszawa 2004.

Różański Jarosław, Postawy polskich misjonarzy wobec miejscowych kultur, w: „Idźcie na cały świat". Kapłani diecezji opolskiej na kontynentach świata, red. S. Klein, J. Urban, Opole 2001.

Słownik literatury polskiej XX wieku, red. J. Sławiński, Wrocław 1992.

Szyszka Tomasz, Głoszenie Słowa Bożego (Ewangelii) jako cel misji, „Lumen Gentium” nr 1, 2012.

Szyszka Tomasz, Podażać za człowiekiem. Perspektywa misjologiczna, w: Misja Kościoła i migracje, red. D. Cichy, Warszawa 2014.

\section{Biogram}

Mgr Sylwia Wójcik - doktorantka literaturoznawstwa na Uniwersytecie Rzeszowskim. Autorka pracy magisterskiej Polonia brazylijska w publicystyce ks. Zdzisława Malczewskiego, która została przetłumaczona na język portugalski i w całości wydana przez Muzeum Historii Polskiego Ruchu Ludowego i Instytut Studiów Iberyjskich i Iberoamerykańskich Uniwersytetu Warszawskiego (2016). Przygotowuje rozprawę doktorską na temat prozy Jana Krawczyka. Jej zainteresowania naukowe obejmują literaturę emigracyjną, współczesne metodologie badań literackich, a także dydaktyczne aspekty literatury.

ORCID: 0000-0002-8209-5810 